ROCZNIKI HUMANISTYCZNE

Tom LXVII, zeszyt 11 - 2019

DOI: https://dx.doi.org/10.18290/rh.2019.67.11-7

IZABELLA KIMAK

\title{
BROWNSTONES WITH STORIES TO TELL: HOUSES IN JONATHAN LETHEM'S THE FORTRESS OF SOLITUDE
}

\begin{abstract}
A b stract. This article constitutes an analysis of the depiction of houses in Jonathan Lethem's 2003 novel The Fortress of Solitude, universally labeled a novel of gentrification. It is my contention that despite being criticized for its alleged celebration of the process the text nevertheless paints a more nuanced picture of gentrification. It does so through the depiction of houses - the titular brownstones of this essay - that function both as a synecdoche for a larger neighborhood or community that they are situated in and as a reflection of the dynamics of the family units that occupy them.
\end{abstract}

Key words: Jonathan Lethem; The Fortress of Solitude; gentrification; racism; houses.

Houses loom large in American society, culture, and imagination. The word "home," with its evocations of warmth, hearth and family, is often linked to notions of safety, stability, and moral rectitude. Home is supposed to offer one rootedness and protection from the influence of the outside world. House ownership lies at the core of the quintessentially American ideas of a self-made man and the American Dream. Houses loom large in American literature, too. There are numerous descriptions of houses in American literary texts, in which the house frequently functions as a trope, as a symbol of self and community and/or as a goal to aspire to. Marilyn Chandler argues in her study titled Dwelling in the Text: Houses in American Fiction that from Thoreau's Walden through Poe's house of Usher and Gatsby's mansion on Long Island to the haunted house of Morrison's

IZABELla KIMAK, PhD - Maria Curie-Skłodowska University in Lublin, Faculty of Humanities, Department of American Literature and Culture; address for correspondence-E-mail: izabella. kimak@poczta.umcs.lublin.pl 
Beloved, "a house stands at stage center [in American literature] as a unifying symbolic structure that represents and defines the relationships of the central characters to one another, to themselves and to the world" (1).

The centrality of the house in American collective imagination is evinced not only by canonical American texts studied by Chandler but also by more recent publications. For example, in Jonathan Lethem's The Fortress of Solitude, a semi-autobiographical novel published in 2003, houses play a significant two-fold role. On the one hand, a house functions as a synecdoche for a larger neighborhood or community it is located in. Neither as material structures nor as literary representations do houses ever exist in some social void; on the contrary, as Dolores Hayden puts it, "[h] separated from their physical and social contexts" (qtd. in Chandler 12). Chandler, in turn, sees houses as "the locus of the central conflicts of American life" and "the stage on which the dramas of sexual politics and class warfare are played out" (6). The statement certainly rings true with respect to Lethem's novel. The facades, interiors and functions of Brooklyn's brownstones presented there reflect the changes that occur in the larger community: from the Gowanus of the main character's childhood in the 1970s to the gentrified Boerum Hill in the early twenty-first century, when the protagonist returns home after a several-year-long absence. On the other hand, houses in Lethem's novel are reflective of the politics and dynamics of the families that occupy them. Seeming to offer a modicum of protection from the outside world, house walls turn out to be permeable, and, hence, the events transpiring outside the house have a bearing on those happening inside. The unstable character of the two single-father households depicted in the text seems a reflection of the tensions and rifts inherent in gentrification, which is at that point literally tearing the neighborhood apart. Thus, the two functions of houses within Lethem's narrative-the commentary their depiction offers on social change and on the families that inhabit them - in a way come together as Lethem's representation of houses engagesand ultimately challenges - the conventional association of home ownership with the notions of safety, stability and middle-class respectability as well as addresses the complexities of racialized and class-based gentrification process.

When The Fortress of Solitude was first published, it was universally labeled "a novel of gentrification" and criticized by some scholars and reviewers for its simplification, or even glorification, of the process. Such an opinion does not seem justified, in my view, as Lethem in his text shows 
gentrification to be a complex process that has a profound-and not univocally positive-impact on individuals and communities. What is definitely true about the text is that gentrification plays a significant role in it, both content-wise and structure-wise. The first section of Lethem's tripartite text-presenting the protagonist at the age of six and on the verge of starting school-introduces the reader to the beginnings of gentrification in a part of Brooklyn called Gowanus. Early in the text, the reader finds out that "[a]n old white woman had arrived on the block . . . to reclaim one of the abused buildings, one which had been a rooming house, replacing fifteen men with only herself and her crated belongings" (Lethem 3 ). The woman, Isabel Vendle, embarks on a mission of turning Gowanus into a more respectable neighborhood-which to her means a "more white" neighborhood-and begins by renaming the area Boerum Hill in an effort to distinguish it from the housing projects located in the vicinity. The account of the renaming presents Isabel as an almost god-like figure that brings a new world to life with a mere movement of her hand: "So, Boerum Hill, though there wasn't any hill. Isabel Vendle wrote it and so it was made and so they would come to live in the new place which was inked into reality by her hand" (7, emphasis in the original).

Interestingly, in Lethem's account of Isabel Vendle's project, the change that the old woman envisions for the area is articulated through the transformations she wishes the buildings to undergo:

The houses here were sick. The Dutch-style row houses had been chopped into pieces and misused as rooming houses for men with hot plates and ashtrays and racing forms, or floor-through apartments, where sprawling families of cousins were crammed into each level, their yards and stoops teeming with uncountable children. The houses had been slathered with linoleum and pressed tin, the linoleum and tin had later been painted, the paint painted again. . . The lines of the rooms, the fine moldings, had been broken by slapdash walls to make hallways, the bathrooms had had Sears Roebuck shower stalls wedged into them, the closets had been turned into kitchens. The hallways had been pissed. These brownstones, these upright Dutch houses, were bodies, bodies abused, but Isabel would make them well again, she'd fill them with couples, renovators who'd replaster the ornate ceilings, refurbish the marble hearths. (Lethem 7-8)

The fragment makes use of the frequent association of the house with the human body: dilapidated after years of misuse, the brownstones are compared to abused bodies in need of treatment. It has to be emphasized, though, that the condescending tone of the fragment with its explicitly 
classist — and implicitly racist — undertones is the product of Isabel Vendle's mind, which the third-person narrator of the first part of Lethem's novel clearly distances himself from by presenting the aging woman in an ironic and decisively unfavorable light. This narrative distance contradicts the opinion of some scholars concerning Lethem's allegedly unreflective and celebratory portrayal of gentrification.

The problem of Brooklyn's gentrification is returned to at the end of the novel, whereby the depiction of the pre- and post-gentrification Dean Street and the surrounding area may be argued to serve as a sort of a frame for the whole text. The grown-up Dylan comes back home so as to come to terms with his troubled past when he was constantly being bullied by his black schoolmates in the public-school system his mother had insisted he attend. $\mathrm{He}$ returns home to reconnect with his childhood friend and neighbor Mingus Rude, his idol and protector from school years and a reference point for his own identity. Upon returning to Brooklyn after a several-year-long stay in Berkeley, Dylan cannot believe his eyes, so radically transformed the neighborhood is:

The place was one of a run of glossy new restaurants and boutiques on the old Hispanic strip, dotted in among the botanicas and social clubs, and the shuttered outlets full of dusty plastic furniture and out-of-date appliances. Abraham [his father] had tried to explain it a dozen times, but there was no understanding until I saw with my own eyes: impoverished Smith Street had been converted to an upscale playground. I suppose it was susceptible to such quick colonization precisely because so many stores had been boarded and dark. The street would be barely recognizable for how chic it had become, except the Puerto Ricans and Dominicans had stuck around. They were refugees in their own land, seated on milk cartons sipping from paper bags, wheeling groceries home from Met Food, beckoning across the street from third-floor sills, trying to pretend gentrification hadn't landed like a bomb. (Lethem 424)

Dylan's reflections on gentrification emphasize the rapidity and violence of the process, which is akin to colonization in that it displaces and uproots the original inhabitants of the area, making them "refugees in their own land." Even though the beneficiaries of the transformation are in general white middle-class people, the mere fact of the white race of the novel's protagonist and the fact that his is the primary voice in the last section of Lethem's novel are, however, not sufficient to claim that "Dylan is an observer of, contributor to, and, ultimately, the beneficiary of gentrification's commodification of inner-city landscapes," as Matt Godbey 
does, adding that "[w]hen Dylan bemoans the loss of a city block that he considers the source of his identity, he reacts not to the upscale changes that have alienated and displaced his former neighbors and friends . . but rather to the loss of the physical referent for the idealized space he's created in his mind as a repository for the black experience that he has adopted for his personal identity" (141). It is true that for Dylan the gentrified area has lost its authentic feeling - thus he calls it a mere "playground"-yet it has never been idealized by him in the first place. Rather, it served as a locus of his childhood traumas related both to his mother's abandonment of the family and his victimization by black kids.

Apart from their role of reflecting societal change, houses in Lethem's narrative function as mirrors of the family units that occupy them. What is idiosyncratic about the homes of the two childhood friends portrayed by Lethem - the white Dylan Ebdus and the black Mingus Rude - is that they are both single-parent households run by fathers and that they are vertically organized into zones controlled by various family members. The position of these zones vis-à-vis one another speaks volumes about the family dynamics and hierarchies operative in the two houses. As Chandler claims, referring to Bachelard's theorization of a house's verticality, "[u]pper, middle, and lower stories, basements and attics, niches and hallways, and threshold and hearths allow us to situate events and people in spatial relations that dramatically express their relative importance" (12). Dylan's childhood house is essentially divided into two spheres, with Dylan positioned somewhere inbetween: the upstairs, where his father Abraham, a visual artist, works on his project, untroubled by the constraints of domesticity, and the downstairs, "[h]is mother's spaces - the parlor full of her books and records, the kitchen where she cooked food and laughed and argued on the phone, her table full of newspapers and cigarettes and wineglasses - [which] were for Dylan full of unpredictability and unrest, like his mother herself" (Lethem 10). Dylan's position in-between the realms of his parents is symbolized by the staircase he constantly drifts up and down. Pulled by his mother's restless energy, he frequently ends up downstairs, from where Rachel would invariably oust him out of the house and into the street, his "second world" (13), so that he would become a street-smart Brooklynite like herself. The house, thus, can be argued to be lacking the center, which for Bachelard is one of the key features of houses. As he claims, "[a] house is imagined as a concentrated being" (17), as a hermit's hut rather than a spacious, multi-room residence. Dylan's father is made to "touch the earth" (Lethem 499) by his wife's 
unexpected disappearance, which forces him to combine his work as a visual artist with domestic responsibilities. The vertical organization of the house - the upstairs, the downstairs and the street - manifests the hierarchy of the family members as well as their link to the world of the mundane: single-mindedly devoted to what will turn out to be his lifelong artistic project, Abraham leaves his wife to earn a living and care for the house and it is her frustration with the family politics that leads to her abandonment of the family.

Rachel replaces the middle-class stability of home ownership with a freedom granted by living in a hippie commune in the Midwest. What Dylan realizes after tracking the place down is that what matters most for one's sense of self is not some stable geographical locale where one puts down roots, but rather a "middle space" that "open[s] and close[s] like a glance" (Lethem 508). The middle space is characterized by its elusive nature. The commune of Watermelon Sugar was once such a space for Rachel, a shortlived locus of freedom and respite. Dylan's conceptualization of the middle space stems from the contrast he sees between his mother and his father and the zones occupied by them. "For so long," he says, "I'd thought Abraham's legacy was mine: to retreat upstairs, unable or unwilling to sing or fly, only to compile and collect, to sculpt statues of my lost friends, life's real actors, in my Fortress of Solitude" (501). This is a kind of home that Dylan wishes to avoid and for this reason he decides to "move on the ground, touch the earth" (501), trying to find his absent mother. At the end of the novel Dylan concludes: "Abraham was the father I never had, and Rachel was the mother I never had, and Gowanus or Boerum Hill was the home I never had, everything was only itself however many names it carried" (506). David Coughlan reads these words as Dylan's "coming-to-terms with a story marked by absence" (213). Still, there is a particular "middle space" that Dylan invests with validity by devoting to it the last paragraph of his account, which is also the last paragraph of Lethem's sprawling text. The outcome of the journey back home comes as a surprise to him: no longer trapped between his parents, as if on the staircase of his family house, he conjures his own middle space as the locus of his self.

The middle space is for Dylan a memory of driving home with his father from Camden College through a blizzard while listening to Brian Eno: "We were in a middle space then, in a cone of white, father and son moving forward at a certain speed. Side-by-side, not truly quiet but quiescent, two gnarls of human scribble, human cipher, human dream" (Lethem 509). The 
inability to pinpoint the localization of the scene precisely as well as the white color that enshrouds all elements of landscape to the point of invisibility prompts the reader to focus on what is happening inside the car: "two gnarls of human scribble," barely talking to each other, and yet in some peculiar way bound together, struggling on against the curtain of white.

Dylan's middle space obviously provokes questions of the symbolism of snow's white color, especially in the context of a novel that specifically probes the relationships between black and white occupants of Brooklyn. White color is linked here to the notion of invisibility, a feature desired by Dylan, who during his school years was hyper-visible on account of his white skin, "his sole white face" (Lethem 19) in the pre-gentrification Brooklyn. Invisibility is one of the tropes frequently deployed by African American writers, perhaps most conspicuously so by Ralph Ellison in Invisible Man, in which invisibility is for the black protagonist an undesirable condition. For Dylan, however, invisibility is the key to safety. Lethem's reversal of the scenario, his presentation of a white boy as the victim of racism as well as his choice of the narrative voice of a white man in the third part to represent the experience of black Americans have earned him a heavy load of criticism for stereotyping and misrepresenting the African American experience. However, as Devika Sharma argues, Lethem is aware of the limitations of his narrative and consciously plays with the notion of cultural appropriation: "the novel self-referentially names its own representational challenges: how to represent black cultural history in a 'white narrative'; how to avoid making assertions of 'the other'; how to depict the conditions of black Americans today without creating simplistic and sentimental stereotypes" (672). Whether he succeeds in doing so is a matter of debate, yet it seems that what Lethem achieves by his portrayal of a white boy suffering at the hands of his black peers is the conclusion that gentrification, or racism for that matter, leaves no community-whether black or white-undamaged.

To conclude, the interiors and exteriors of the houses lining Dean Street that Lethem depicts in The Fortress of Solitude serve specific narrative functions. On the one hand, they are inextricably connected with gentrification and provoke reflections on the radicality of the process. Just like the partitions added by the former lower-class non-white occupants are torn down to restore the brownstones to the condition deemed proper for and by white middle-class newcomers, the communities inhabiting the area are likewise torn apart and divided by access to home ownership and other 
symbols of middle-class status. On the other hand, the internal organization of Dylan's home-with its division into lower and upper stories-serves as a metaphor for the conflicting influence of his parents upon the boy. His own sense of who he is is best symbolized by the staircase, which at the end of the novel is replaced by the middle space that Dylan conceptualizes as the locus of his identity based on the choices he himself makes as to what to take from his past and what to leave behind, which makes the reader feel that at the end of the novel, in his early thirties, Dylan is finally able to come to terms with what Coughlan calls his "discontinuous identity" (213).

\section{WORKS CITED}

Bachelard, Gaston. The Poetics of Space: The Classic Look at How We Experience Intimate Places. 1958. Translated by Maria Jolas. Beacon Press, 1994.

Chandler, Marilyn R. Dwelling in the Text: Houses in American Fiction. University of California Press, 1991.

Coughlan, David. "Jonathan Lethem's The Fortress of Solitude and Omega: The Unknown, a Comic Book Series." College Literature, vol. 38, no. 3, 2011, pp. 194-218.

Godbey, Matt. "Gentrification, Authenticity and White Middle-Class Identity in Jonathan Lethem's The Fortress of Solitude." Arizona Quarterly: A Journal of American Literature, Culture, and Theory, vol. 64, no. 1, 2008, pp. 131-151.

Lethem, Jonathan. The Fortress of Solitude. Vintage Books, 2003.

Sharma, Devika. "The Color of Prison: Shared Legacies in Walter Mosley's The Man in My Basement and Jonathan Lethem's The Fortress of Solitude." Callaloo, vol. 37, no.3, 2014, pp. 662-675.

\section{KAMIENICE Z HISTORIAMI DO OPOWIEDZENIA: DOMY W POWIEŚCI TWIERDZA SAMOTNOŚCI JONATHANA LETHEMA}

\section{Streszczenie}

Niniejszy artykuł stanowi analizę opisów domów w wydanej w 2003 r. powieści Jonathana Lethema Twierdza samotności. Uznana za powieść o gentryfikacji i szeroko krytykowana za rzekomą jej celebrację, powieść szkicuje dużo bardziej wyważony obraz procesów gentryfikacji. Dzieje się tak dzięki reprezentacjom domów, tytułowych brooklyńskich kamienic, które funkcjonują zarówno jako synekdocha okolicy czy społeczności, w której się znajdują, oraz jako odbicie dynamiki rodzin je zamieszkujących.

Słowa kluczowe: Jonathan Lethem; Twierdza samotności; gentryfikacja; rasizm; domy. 